\title{
'Language is a costly and complicating factor': A diachronic study of language policy in the virtual public sector
}

This article examines language policy in the virtual linguistic landscape (VLL) in Norway and its development over time. The analysis is based on diachronic website data and interviews with state employees concerning the presence or absence of different languages on the websites of three central state institutions. The article reveals a linguistic homogenization of the VLL of the public sector in Norway, which is mostly due to the removal of immigrant languages from state websites. The analysis also shows an increased linguistic presence of Nynorsk (the less used written standard of Norwegian), of the indigenous Sámi language, and of English, which performs a 'hypercentral' function. The virtual linguistic ethnography and follow-up interviews show that the websites of the three institutions in focus exist more or less fully only in two language versions: Bokmål, the more widespread written standard of Norwegian, and English. The translations into Nynorsk and Sámi are mainly done to comply with official regulations. In addition, immigration, rather than leading to an increased visibility of language diversity in the VLL, can also put pressure towards homogenization. One could perhaps even go so far as to see Norway as the harbinger of change: once multilingualism has reached its peak, there is a chance that more and more state institutions will cut down on 'less than necessary' languages online, opting instead for 'commonsense' English together with the respective national language.

Keywords: Norway; Sámi; Nynorsk; virtual linguistic landscape; online language policy; state websites.

\section{Introduction}

In contemporary societies in many parts of the world, numerous online services are replacing what was previously provided by a customer service agency or public utility with a physically present person at the other end. In technologically advanced countries, state websites have become a central platform for communication between the state and the people. Ivković and Lotherington (2009) consider state websites to be an element of what they term virtual linguistic landscapes (VLL), broadening the linguistic landscape (LL) paradigm to include the representation of languages in publicly accessible digital spaces (see also Deumert 2014). The 
epithet 'virtual' here is meant to index the 'non-physical' LL realized by the Internet and digital technologies, and not to denote that these landscapes are imagined or unreal. Importantly, using the state websites in focus can have an effect on the users' lives, which is hardly less real than going to a physical service center of the same institutions.

A number of scholars (Atkinson and Moriarty 2012; Deumert 2014; Thorne and Ivković 2015; Troyer 2012) have examined the LL of various online environments, most of them focusing first and foremost on user-generated content, or Web 2.0. This article examines language policy on three central state websites in Norway and its development over time. The websites of the state institutions examined in this study (the Norwegian Tax Administration, the Norwegian Labour and Welfare Administration, and the Norwegian Directorate of Immigration) belong to what Hine (2000) calls a 'repository of texts' (the monologic Web), in contrast to 'Web as interactive space' (the dialogic Web). Other items of the monologic Web include, for example, search engines, gateway sites, corporate websites, and to a certain extent, news portals. They are primarily characterized by one-way communication and can be regarded as closer to 'old' or 'traditional' media (Kelly-Holmes 2015: 132-133), allowing for the investigation of how national policies are implemented in cyberspace in a top-down way. The focus on Norway brings to attention the use of indigenous languages (in this case, Sámi), immigrant languages, as well as English in online state communication regulated by official legislation, and parallels with other European nation-states can be drawn. Furthermore, the linguistic situation in Norway is rendered even more complex by the existence of two official written standards of Norwegian: Bokmål and Nynorsk; the use of these varieties on state websites is also problematized in this article.

An examination of the institutional VLL can provide important insight into the interconnections between official language legislation, language ideologies, and language practices. Items of the LL are 'mechanisms of language policy that can perpetuate ideologies and the status of certain languages and not others' (Gorter 2013: 197; Shohamy 2006). Linguistic representation in the state-governed VLL 'transmits symbolic messages as to the legitimacy, relevance, priority and standards of languages and the people and groups they represent' (Shohamy 2006: 110) and can thus be seen as a reflection of power relations and social ordering in the Norwegian society. As Deumert (2014: 55, discussing Hall 1997) puts it, 'representation is not only about reflecting - more or less accurately - an existing state of affairs in a different medium, but is also constitutive of reality'. In her discussion of the power of visual multilingualism, Kelly-Holmes (2014: 137) emphasizes that the way we see a 
language is 'pre-formed and then either reinforced or challenged' by the visibility of multilingualism or monolingualism on a daily basis. The visibility and use of different languages on state websites can thus influence the perception of these languages and their relative positioning in the society.

Some researchers (Blackwood 2015; Pavlenko 2010) have taken a diachronic approach to the study of LL. The analysis in this article draws on diachronic website data collected with the help of The Internet Archive, tracing the developments in the use of different languages on the websites of the three Norwegian state institutions from their respective year of launch until 2014. The article further brings in an additional focus, namely that of the actors behind the creation of the VLL, in order to explain the changes in language use over time, as well as the current language policy at the specific institutions. The languages displayed in items of the physical and virtual LL are closely related to people who create them, and it is important to understand the motives, ideologies and decision-making of these people. This can be achieved by taking a more ethnographic approach as a way of providing deeper understandings of the context, including the production and reception of the LL. Numerous studies have focused on the actors behind bottom-up LL items through combining the description and analysis of the LL with interviews with the decision makers, such as shop, restaurant and company owners (Malinowski 2009; Stjernholm 2015; Zabrodskaja 2014). In order to bring out the institutional challenges connected to choosing communication strategies and to making compromises in realizing policies, the analysis in this study is supported by interviews with the employees who are directly responsible for the creation and/or implementation of communication strategies.

Below I will first provide a brief overview of the linguistic situation in Norway and of the language and communication policies that regulate language use on central Norwegian state websites. This will be followed by a further explanation of the multi-methods approach chosen for this study. I will then present and discuss the results of the study, and focus in more detail on the use of immigrant languages, Nynorsk (the less used written standard of Norwegian), Sámi, and English on the websites of state institutions in Norway. The paper reveals recent linguistic homogenization of the VLL created by Norwegian state institutions and discusses the variety of reasons for this development together with its possible broader implications. 


\section{Language policy for online state communication: the case of Norway}

The linguistic situation in Norway is both typical and unique in relation to other European nation states in the contemporary era. There are two parallel standards of written Norwegian: Bokmål and Nynorsk. Furthermore, Sámi, Kven, Romanes and Romany are recognized as regional or minority languages and protected by the European Charter for Regional or Minority Languages (Gramstad 1996). Finally, immigrants and Norwegian-born people with immigrant parents constitute around $16.3 \%$ of Norway's total population of 5.2 million (Statistics Norway 2016). The mostly labor- or refugee-driven immigration to Norway has its origin in a large number of countries: Poland, Lithuania, Sweden, Somalia, Pakistan, Iraq, Germany, Vietnam, the Philippines, and many more. Poles are the largest immigrant group in the country, constituting almost $14 \%$ of the total immigrant population. These sociolinguistic features of contemporary Norway will be discussed in more detail in connection with the results.

In recent years, state institutions in Norway have rapidly been moving a significant part of their communication with the public to the Internet, and are faced with the question of language choice for communication with different types of linguistic minorities. For communication with state institutions, online registration is often required in order to get an appointment in person. Norway is one of the most advanced countries for Internet connectivity and use of digital services in the world, with an Internet penetration rate of $95 \%$ (World Economic Forum 2015). In 2000, the country implemented a national information and communications technology (ICT) policy called 'eNorway' with the goal of placing Norway and its population solidly in the center of the 'knowledge economy' in terms of the use and development of ICT. According to the Digitising Public Sector Services - Norwegian eGovernment Program (2012), the public sector in Norway is to be 'digital by default', with digital communication as the main means of communication with the public administration. Similarly, the Digital Agenda for Norway (2013) states that Web-based services are to be the default for the public sector's communication with citizens and organizations, and emphasizes its goal of 'genuine digital participation by everyone': services must be designed in such a way that most people can use them. In the case of technologically advanced countries like Norway, we are dealing with the notion of a virtual public sector, or technologically mediated communication between the state and the people. The allocation of space and visibility to 
specific languages on state websites can thus be seen as a symbolic construction of this virtual public space (Ben-Rafael et al. 2006).

There are a number of organizations that have regulative power in cyberspace, among them network operators, software producers, and national governments (Bortzmeyer 2012). The use of different languages on official governmental websites is usually regulated by the same policies that apply to them in offline contexts (Kelly-Holmes 2015: 131). Consequently, in Norway, there exist different national policies that regulate language choice and use on official state and municipal websites. Two of the top-down policies that are central for the present study are the Language Act (Mållova 1980) regulating the use of Bokmål and Nynorsk in written state communication, and the Sámi Act (Sameloven 1987), which emphasizes the importance of the linguistic presence of Sámi in official communication. Furthermore, according to the Central Government Communication Policy (2009) (a continuation of the Information Policy from 1994, with a revision in 2001), each institution decides for itself which languages to add for communication with the immigrant population. In this way, state institutions in Norway have some decision-making authority over the use of different languages on their websites. These three policies will be further discussed in the sections below.

\section{Data and method}

The focus of this article lies on three state institutions in Norway: the Norwegian Tax Administration (Skatteetaten), the Norwegian Labour and Welfare Administration (Nye arbeids- og velferdsetaten, usually referred to as NAV), and the Norwegian Directorate of Immigration (Utlendingsdirektoratet, usually referred to as UDI). These institutions were explicitly chosen because they are central to the meeting between the authorities and the public. They communicate with most of the adult population of the country (and with those who wish to come to Norway): the employed (Tax Administration), the unemployed and others receiving social benefits (Labour and Welfare Administration), and applicants for (an extension of) a residence permit, whether they are already in Norway or wish to enter the country (Directorate of Immigration). Such central state institutions can be considered 'major discourse nodes' and their public language use is more likely 'to contain traces of ideologies and also to have an impact on their reproduction' (Ajsic and McGroarty 2015: 185). 
The study has a multi-methods approach and uses two sources of data: website data (the actual online practices) and semi-structured interviews (explanations of the practices by institutional employees). Kelly-Holmes (2015) proposes 'virtual linguistic ethnography' as a way to investigate language policy in new media. This approach combines virtual ethnography (Hine 2000) with linguistic landscape analysis (Landry and Bourhis 1997), linking ethnographic sensitivity with an investigation of the visibility and functions of different languages in cyberspace.

State websites are well suited for an examination of 'the degree of compliance with relevant local language legislation or de facto policy in cases where no legislation exists' and the role of English (Kelly-Holmes 2015: 133). In order to trace the development of language policy in the VLL created by the institutions in focus, the study takes a diachronic approach. Kelly-Holmes (2015: 135) describes such an approach in her framework for studying monologic sites: 'Record changes in language provision and content over time in order to track the emergence of language policies'. It is possible to collect diachronic data on websites with the help of The Internet Archive, which provides a unique tool called Wayback Machine (https://archive.org/web/) that records and archives past versions of websites, allowing detailed insight into their development and encouraging 'reflection on the specificity of the present' (Hine 2015: 75). This tool does not simply provide a screenshot of the website, but makes it possible to enter the site and navigate it as it was back in time (see Figure 1). This way, instead of gathering and storing screenshots or downloading and archiving material from the site, it is possible to re-enter and thoroughly browse the website. For this study, I focused on two levels of the website architecture: the front page in all the available languages and the pages that were referred to through links on the front page. 


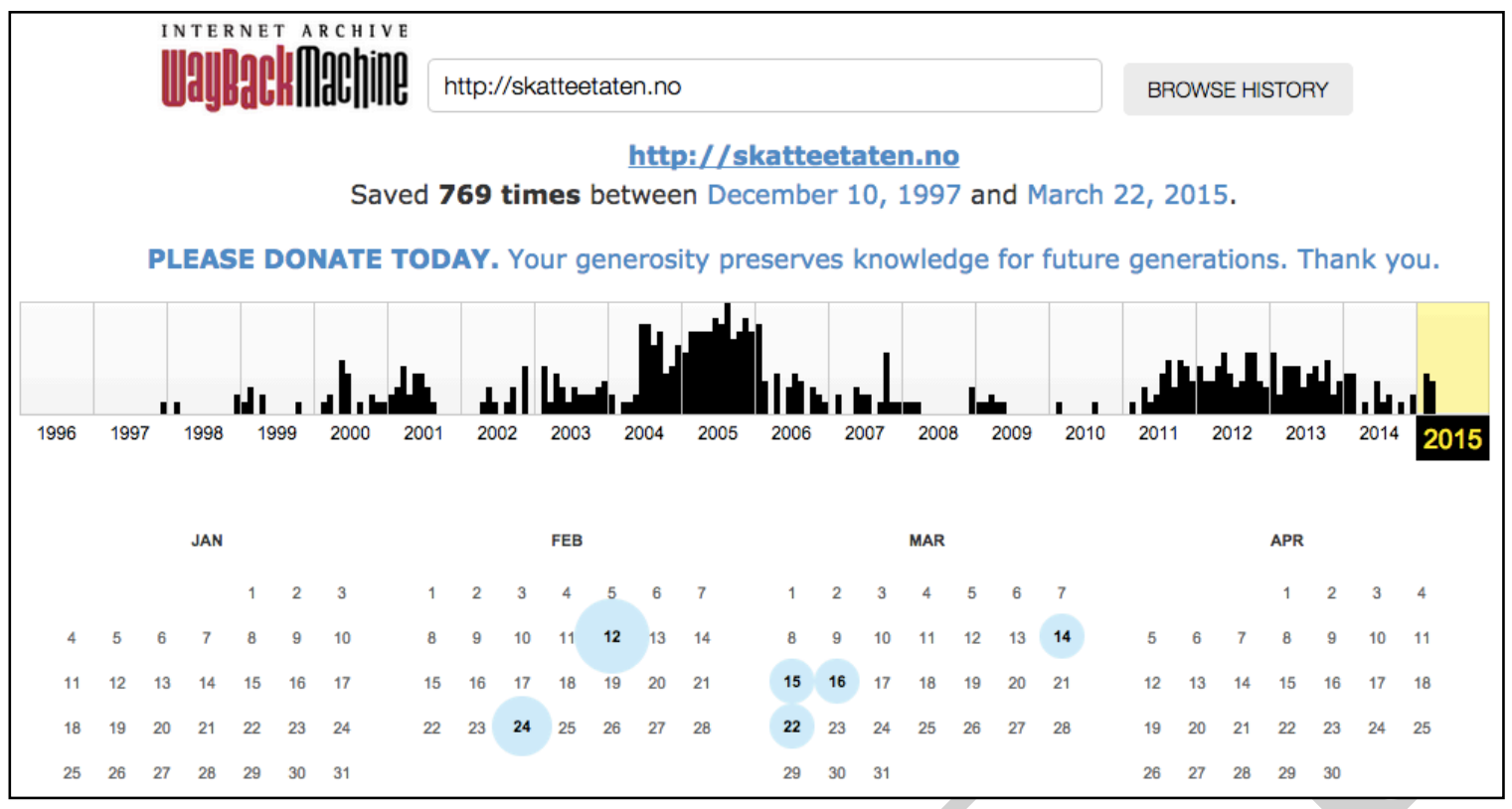

Fig. 1 Wayback Machine: A search for the history of the website of the Norwegian Tax Administration. The timeline provides a shortcut to various time periods, while the blue circles in the calendar below mark the dates when it is possible to enter an archived version of the website.

In order to investigate the reasons behind the specific language policy related choices of the institutions in focus, I interviewed state employees ${ }^{1}$ who interpret and implement the official policies in practice, and who in their everyday work deal with managing communication with the linguistically diverse audience of the institutions. Altogether three semi-structured interviews were carried out in 2014 in Oslo (one at each of the institutions in focus), with follow-ups over e-mail. The topics that formed the basis for the interviews were the following: (1) the procedures for creating webpages in different languages, reasons behind the specific linguistic and content related choices, and maintenance of the website; (2) the use of different languages in oral communication by the institution (call center, personnel at the client service centers, interpreters); (3) the importance of online communication with the public for the specific institution and for Norway's public services in general. The interviews were conducted in Norwegian, recorded, and transcribed, and the excerpts used in this article were translated into English by the present author.

\section{Findings and discussion}

${ }^{1}$ I agreed to anonymity, so the job titles of the interviewees are not mentioned in this study. 
In this section I will first present an overview of the general findings of the study concerning the presence of different languages on websites of the three Norwegian state institutions from a diachronic perspective (see also Table 1). As the study demonstrates that Nynorsk, Sámi and English appear to have an increasing linguistic presence in the Norwegian virtual public sector, they will be further discussed in more detail in the following three sub-sections.

4.1. A diachronic overview of language use on Norwegian state websites

The diachronic data show that when state institutions in Norway first launched their websites (for the three institutions in focus that happened in 1997, 1998, and 2006), interaction with the public and providing access to facilities (such as submitting a tax return and sending in an application for a residence permit or parental benefits) online was not their primary goal. These online platforms were instead used to give information about the specific institutions' purposes and aims, list the locations and opening times of their service centers, as well as publish statistics and news. This makes sense because until relatively recently, techonological development did not allow for creating interactive platforms and processing large amounts of user data. Figure 2 shows the information available on the English front page of the Directorate of Immigration in 2004. The page is characterized by static rather than interactive content and is a typical example of one-way information provision by Norwegian state institutions in the past. 


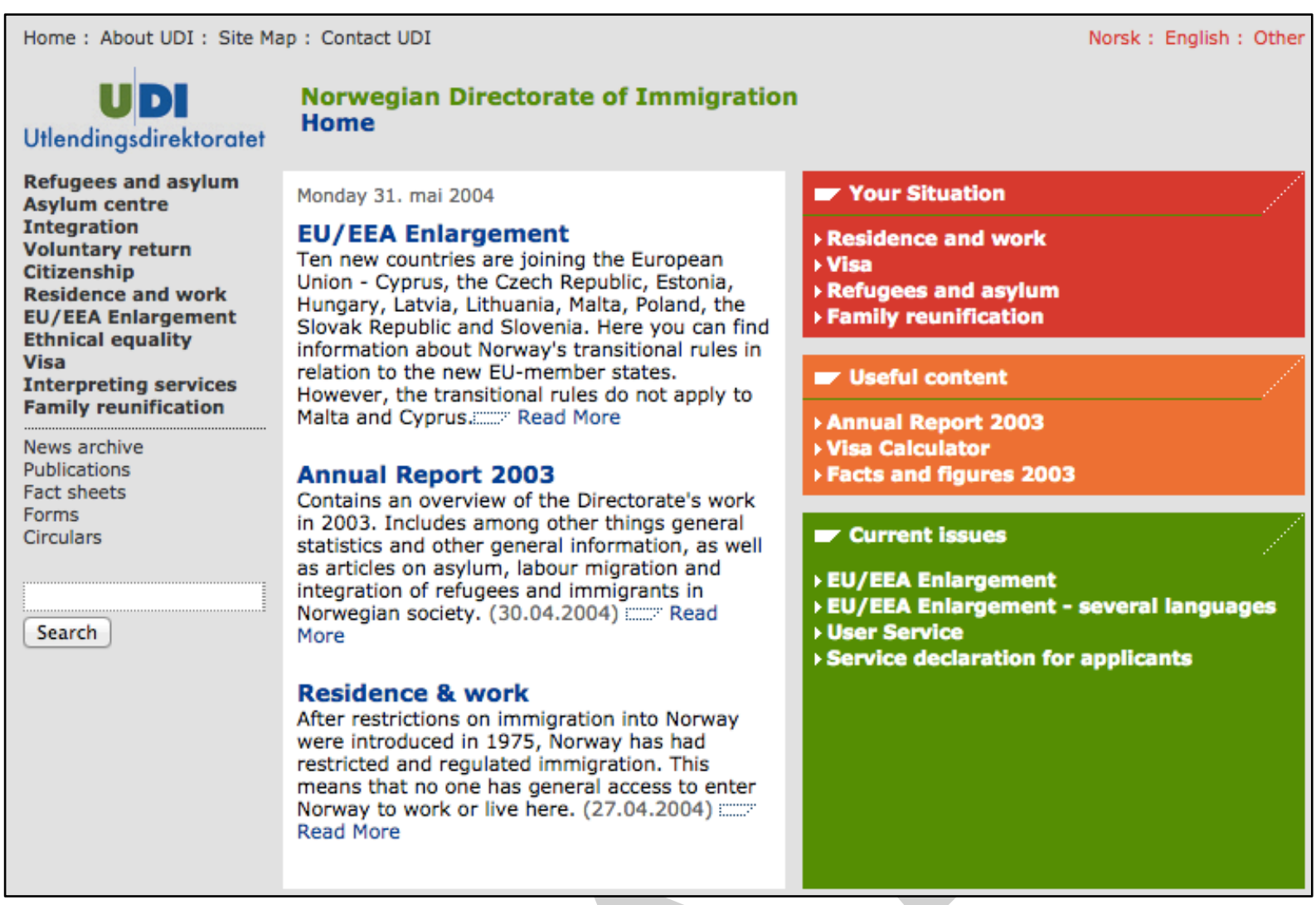

Fig. 2 A screenshot of the English front page of the Norwegian Directorate of Immigration website, from the Wayback Machine archive, 07.06.2004.

Figure 3 shows the English front page of the same institution in 2016 (this revised and updated version of the website was launched in April 2014). As we can see, this page is now characterized by various prompts to action, together with practical information for applicants. Information about the institution, immigration statistics, and other static material has been moved to the bottom of the page and is significantly less visible than before. My informant at the Tax Administration emphasized this trend for increasingly dynamic websites and pointed out that in the last couple of years, there has been a change in attitude and awareness in connection to creating what are now considered good websites. One of the main reasons given for this is that most organizations have an ambition to have their services digitized, so that people can find information and manage their affairs themselves online, and this can be hard to manage in parallel in many languages. 


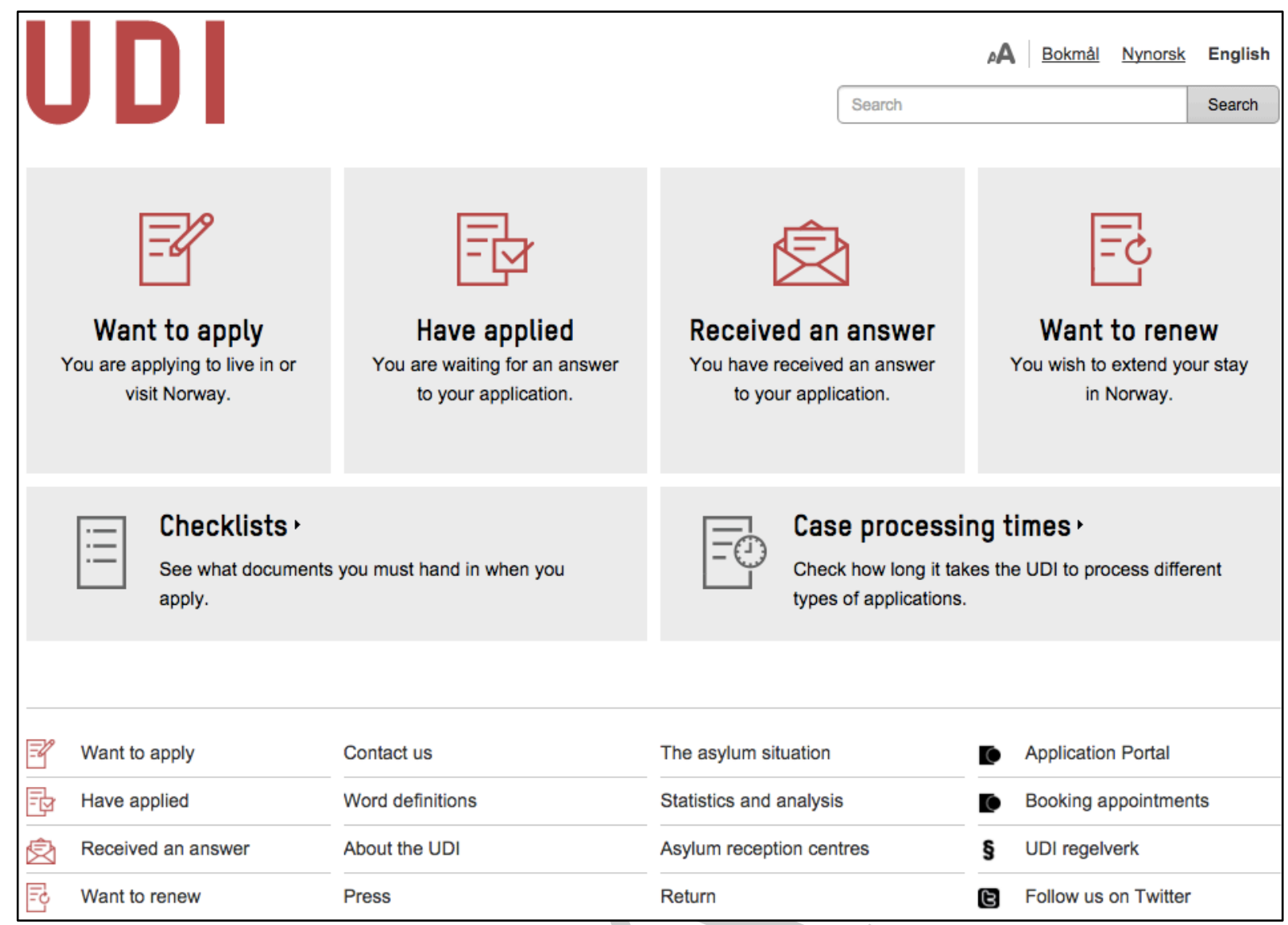

Fig. 3 A screenshot of the English front page of the Norwegian Directorate of Immigration website, 18.01.2016.

An overview of the languages used on the websites of the institutions in focus in the year of their launch and in 2014 is presented in Table 1, together with additional insight into two years in between. These two additional years were chosen because it was at this time that there were most changes in the number of languages available on the specific websites. An important point to make is that when a state website lists 'Norwegian' as a language option, it would normally mean a mix of both Bokmål and Nynorsk; however, Bokmål would be the primary one. Distinguishing a Nynorsk domain as a separate option can thus be regarded as a marked choice.

\begin{tabular}{|l|l|l|l|l|}
\hline $\begin{array}{l}\text { Norwegian } \\
\text { Directorate of } \\
\text { Immigration }\end{array}$ & 1998 & 2000 & 2010 & 2014 \\
\cline { 3 - 5 } & Norwegian & Norwegian & Norwegian, English, Amharic, & Bokmål \\
& & English & Bosnian/Croatian/Serbian, & Nynorsk \\
& French & German, Spanish, Estonian, & English \\
& & French, Kirundi, Latvian, & \\
& & Lithuanian, Polish, Romanian, & \\
& & Albanian, Somali, Tigrinya, & \\
& & Turkish, Arabic, Bulgarian, & \\
& & Dari, Farsi, Nepali, Pashto, & \\
& & Russian, Sorani, Tamil, Thai, & \\
\hline
\end{tabular}




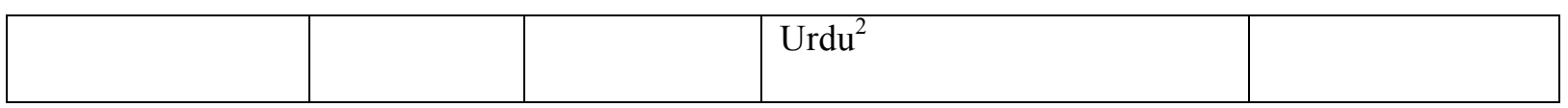

\begin{tabular}{|l|l|l|l|l|}
\hline $\begin{array}{l}\text { Norwegian } \\
\text { Labour and } \\
\text { Welfare } \\
\text { Administration }\end{array}$ & 2006 & 2010 & 2011 & 2014 \\
\cline { 2 - 5 } & Norwegian & Norwegian & Norwegian, English, Sámi, & Norwegian \\
& & $\begin{array}{l}\text { English } \\
\text { Sámi } \\
\text { Polish }\end{array}$ & $\begin{array}{l}\text { Polish, German, Arabic, } \\
\text { Somali, Urdu }\end{array}$ & $\begin{array}{l}\text { English } \\
\text { Sámi }\end{array}$ \\
\hline
\end{tabular}

\begin{tabular}{|l|l|l|l|l|}
\hline Norwegian Tax & 1997 & 1999 & 2009 & 2014 \\
\cline { 2 - 5 } Administration & Norwegian & Norwegian & Norwegian & Bokmål \\
& & English & $\begin{array}{l}\text { English } \\
\text { Polish }^{3}\end{array}$ & Nynorsk \\
& & & $\begin{array}{l}\text { English } \\
\text { Sámi } \\
\text { Polish }\end{array}$ \\
\hline
\end{tabular}

Table 1. A diachronic overview of the languages used on Norwegian state websites.

What these examples show is that there were earlier attempts to add extra languages to online communication by Norwegian state institutions, largely in order to reach the immigrant population. However, the information available in these languages was highly limited and often stigmatizing. For example, the Arabic and Somali versions of the website of the Labour and Welfare Administration only provided information in the form of a PDF file with an English title 'Do you have financial problems?' which opened in a separate window in the respective languages (see Figure 4). On the Russian webpage of the Directorate of Immigration one could only find information for unskilled workers and asylum seekers, while the Urdu webpage did not even contain one word of Urdu but only a link 'See information in English'.

\footnotetext{
2 The order of languages is the same in which they were listed on the website.

${ }^{3}$ Polish was added on a separate domain (taxnorway.no), which was linked to from the top menu on the front page of the Norwegian Tax Administration, but has never been listed in the 'Language' dropdown menu (where Bokmål, Nynorsk and Sámi have been listed since 2013). Adding Polish correlates with the significant increase in the number of Polish immigrants to Norway between 2007 and 2009, which more than doubled in this period, increasing from 17.747 to 42.471 (Statistics Norway 2016).
} 


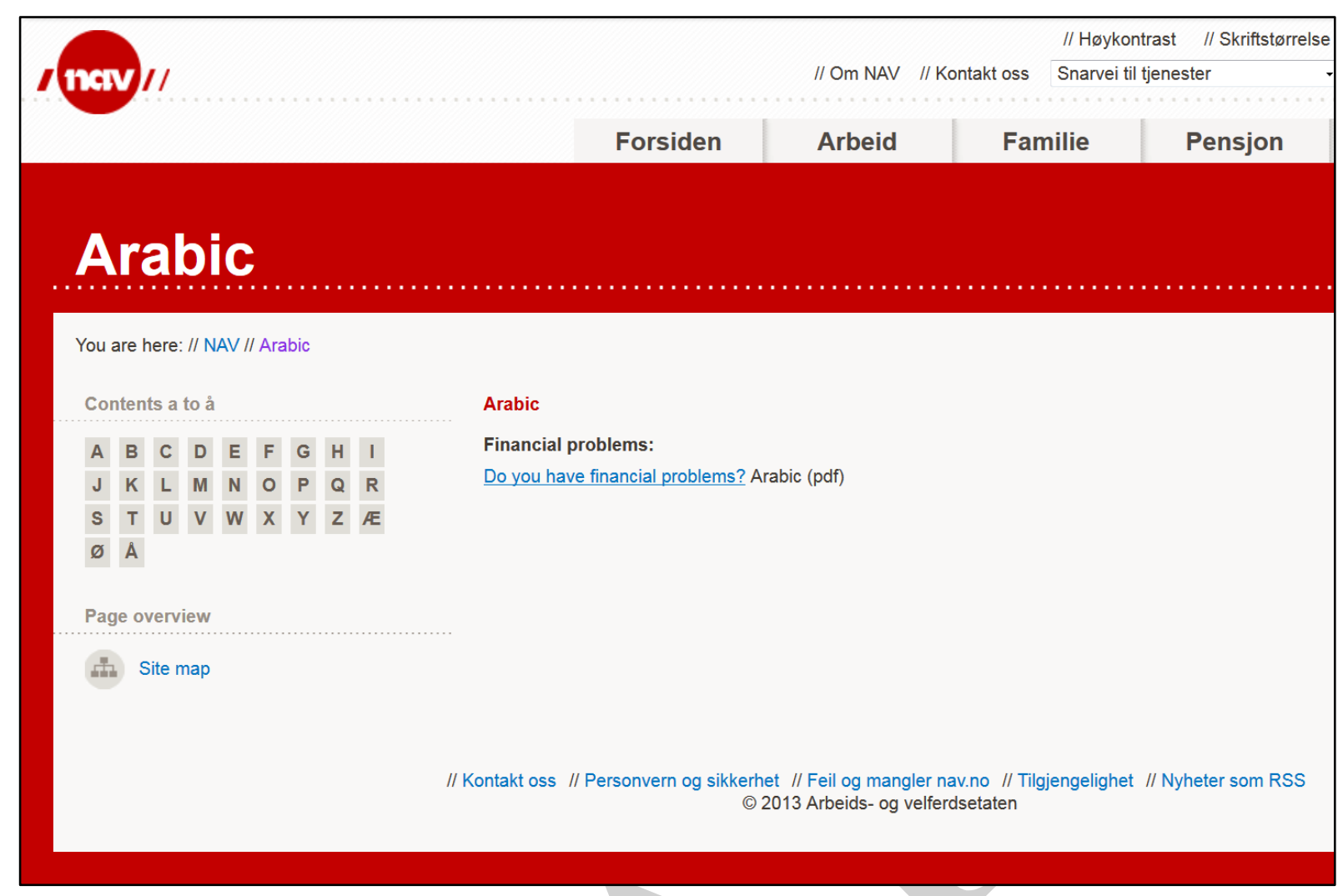

Fig. 4 A screenshot of the Arabic page of the Norwegian Labour and Welfare Administration website, from the Wayback Machine archive, 04.09.2013.

When asked about the reasons for having had pages in immigrant languages in the past despite a lack of their significant practical implications due to the highly limited content, my informant at the Labour and Welfare Administration responded as follows:

Det var en periode hvor man liksom bare oversatte mye for å virke altså virke inkluderende på et eller annet vis, men kanskje uten å sjekke hvor mye de tekstene ble brukt eller var riktig. [...] Det var litt tilfeldig hva som hadde blitt oversatt til andre språk, det var kanskje ikke ut fra brukerbehov, men ut fra at noen trodde eller fordi man skulle vise at man kunne mange språk eller ja.

There was a period when you sort of just translated a lot in order to seem, well, to seem inclusive in one way or another, but perhaps without checking how much those texts were used or correct. [...] It was a bit random what had been translated into other languages, it was perhaps not based on user needs but on that someone thought or because you wanted to show that you could speak many languages or yeah.

As this quote shows, maintaining a multitude of language versions of a website was first and foremost important for self-representation and portraying the institution as multilingual, rather than for meeting the real communication needs of the users. However, as digital communication has become the primary and not just a supporting medium of state communication and information dissemination to the public for state institutions, it is 
increasingly crucial for official websites to be easy to use and up-to-date. Norwegian state institutions seem to be renegotiating their priorities and are now providing more information but in fewer languages.

A further explanation for reducing the number of languages available can be found in the words of my informant at the Directorate of Immigration:

Det som vi prøvde på tidligere med å ha mange språk, det greier vi ikke å leve opp til. Vi greier ikke oppdatere og vi mista kontroll med det. Og det er relativt lite brukt. [...] Og så har vi da i tillegg til den her tar vi jo hensyn til at asylsøkere da som kanskje kan bare det språket, sitt eget språk, dem vil få tolk og vil få en muntlig bistand. [...] Våre nettsider vil ikke voere deres kanal inn.

What we tried before with having many languages, we don't manage to live up to it. We don't manage to update and we lost control over this. And it's relatively little used. [...] And then in addition to this, we take into consideration the asylum seekers, right, who perhaps only know that language, their own language, they will get an interpreter and will get verbal assistance. $[\ldots]$ Our websites will not be their way in.

Similar practical reasons and, most importantly, economic considerations for removing information in immigrant languages were mentioned numerous times in the interviews. As formulated by my informant at the Tax Administration, 'language is a costly and complicating factor when you enter the big systems'. Such a tendency indicates the relatively low value of immigrant languages for the institutions and on the Norwegian linguistic market (Bourdieu 1991) in general. So, while the expenses of translating an entire website into English were not mentioned in the interviews as a budgetary challenge, removing a couple of information sheets in immigrant languages was, at least partially, explained by translation and maintenance costs. With the removal of immigrant languages from the websites of the three institutions, communication in these languages now happens through face-to-face interaction with the help of interpreters, and systems are also in place for using an interpreter over the phone. Without doubt, it can be challenging to create and maintain fully functioning virtual service centers in multiple languages. However, while translating a language version of the entire website is indeed a large investment, it would be possible to have at least a minimum of information available in immigrant languages (for example, a translation of 'If you need interpreting help, please call this number') without any significant costs. Furthermore, providing a comprehensive and flexible interpreting service can be more expensive than partial website translation. Decisions to stop allocating any resources to translation of a website into a specific language should thus be seen as a matter of prioritization rather than a necessity. 
4.2. Nynorsk - 'an eternal struggle'

Nynorsk (or New Norwegian) was created on the basis of Norwegian dialects during the mid19th century and has since 1885 been recognized as an official written standard alongside Bokmål ${ }^{4}$, historically a Norwegianized variety of Danish. Haugen (1962) described the complexity of the dual linguistic situation in Norway with two written standards of Norwegian as 'schizoglossic'. Officially, Nynorsk has equal status to Bokmål. However, in reality Bokmål is used more widely, and the Nynorsk-writing population can be seen as a minority on the national scale (Røyneland 2013). In her discussion of the de facto status of Nynorsk, Bull (2004) comes to the conclusion that Nynorsk can be considered a minority language based on the number of users and its asymmetric relationship to Bokmål.

Today, Nynorsk is used as the primary written standard by around $10-15 \%$ of Norway's total population. It is regionally concentrated in rural western Norway, which makes it to a large degree marked in the geographical and sociocultural context, connecting such associations to it as 'regional', 'peripheral', and 'traditional' (Mæhlum 2007; Røyneland 2013: 59). While all children in the country learn both official standards in school, they choose one of them to be the primary and the other the secondary one. On the national scale, only $6.4 \%$ of the pupils chose Nynorsk for their final exams in 2015 , compared to $7.4 \%$ five years earlier (Grepstad 2015: 147). The use of Bokmål and Nynorsk in state communication was initially regulated by the Language Act (Mållova 1980). According to Section 8 of the Act, the government bodies that cover the whole country are linguistically neutral and should alternate between Bokmål and Nynorsk, so as to create and maintain 'a reasonable quantitative distribution between them' (my translation). In written communication, state institutions must respond in the same standard - Bokmål or Nynorsk - as the one in which they were contacted (Section 6). Furthermore, on websites, in reports and in other written material produced by these institutions for the public, neither of the standards should be represented by less than $25 \%$. However, the interviewees at all three institutions studied in this article reported a difficulty in reaching this goal. My informant at the Labour and Welfare Administration said the following about the use of Nynorsk on their websites:

\footnotetext{
${ }^{4}$ Nynorsk and Bokmål were given their current names in 1929 and were formerly called Landsmål and Riksmål respectively.
} 
Vi har vel ikke tjuefem prosent nynorsk, for selv om vi oversetter en del så øker jo ofte bokmålstekstene enda mer. [...] [Det er] staten som bestemmer og så prøver vi å nå opp til det, men lykkes dessverre ikke alltid helt, for at det økes alt for mye. [...] Så det er en sånn evig kamp. [...] De fleste skriver bokmål, også folk som egentlig kunne skrevet nynorsk. [...] Så er det sånn å minne dem på at vi skal ha noe nynorsk.

Well, we don't have twenty-five percent Nynorsk because even though we translate quite a lot, the amount of texts in Bokmål often increases even more. [...] [It is] the government who decides, and then we try to reach up to it but unfortunately do not always completely succeed because it increases way too much. [...] So it's like an eternal struggle. [...] Most people write Bokmål, also those who would actually be able to write Nynorsk. [...] Then one has to sort of remind them that we must have some Nynorsk.

As this quote illustrates, Bokmål is treated as the 'default' standard and appears to have more authority inside the institution, while Nynorsk has a lower status. One important reason for choosing Bokmål over Nynorsk was mentioned further on in the same interview, namely that the majority of the sources the employees refer to in writing are in Bokmål. For example, the three most widely read newspapers in the country ( $V G$, Dagbladet, and Aftenposten) all have an editorial ban regarding Nynorsk (Noregs Mållag 13.01.2014; see also Indrebø Ims 2007). This way, despite official regulations about the neutrality of state institutions regarding the two written standards, the linguistic choices made by the institutions and the individual employees are far from neutral.

Mæhlum (2007: 198) suggests that if Nynorsk is to represent a real counterforce to Bokmål and have a stronger position in Norway's linguistic market, it should be more associated with values connected to 'the modern world' and progress. Cyberspace is without doubt one of the sectors associated with progress, and an increased presence and use of Nynorsk in the VLL could be beneficial to its status in Norway. Nynorsk has a weak linguistic presence on the Web: in 2015, an estimated 5\% of documents on websites in Norwegian were in Nynorsk (Grepstad 2015: 192). Furthermore, according to a study by Kornai (2013), the proportion of user-generated content in Nynorsk is less than 1\%. Kornai's (2013: 2) conclusion does not give much hope to Nynorsk online: 'In spite of a finely balanced official language policy propping up Nynorsk, the Norwegian population has already voted with their blogs and tweets to take only Bokmål with them to the digital age'. Although such a prediction should be taken with extreme caution, it does indicate a tendency for Nynorsk to be used significantly less online than Bokmål. This makes it even more important for the institutions of the Norwegian state to support Nynorsk on their websites. 


\subsection{Sámi in the institutional VLL}

During the last decades, the Sámi society in Norway has undergone an ethnic and cultural revival (Hansen 2011; Mæhlum 2007). From approximately 1850 to 1959, the Sámi people in Norway were subject to a strict linguistic and cultural assimilation policy, the so-called fornorskningspolitikken, or 'Norwegianization policy' (Hansen 2011; Hiss 2013). The school curriculum from 1880 banned the use of Sámi in school, even as an auxiliary language, and a system of boarding schools was introduced where children lived in isolation from their parents and were forbidden to use Sámi even in their free time (Trosterud 2005; Trosterud 2008). As a result of this policy, which was accompanied by strong stigmatization, many Sámi speakers gave up their mother tongue and shifted to Norwegian. It was only in the 1980s that numerous measures were taken for the protection of the Sámi culture and language. Importantly, an educational system in Sámi from kindergarten to college was created. The Sámi Act from 1987 declared Sámi and Norwegian languages to have equal standing in Norway, and the Sámi Parliament was established in 1989. In 1990, the Norwegian Government amended the Sámi Act to make Sámi an official language in the Sámi Language Administrative District made up of six municipalities in Northern Norway (later a further four have been incorporated). The inhabitants of this district have the right to use Sámi in communication with public authorities, health services, the church, and to encounter Sámi on public signs (Hiss 2013: 179; Puzey 2012).

The Norwegian National Registry does not provide statistics on the number of Sámi in Norway, and it is difficult to say with any certainty how many Sámi live in the country today. The reason for this is that people identify themselves as Sámi on different grounds such as linguistic competence, ancestry, place of residence and profession, and sometimes divisions as to whether people define themselves as Sámi or not, can also be within the same family (Hansen 2011). Some individuals with Sámi background are reluctant to identify themselves as such due to the stigma that still remains from the Norwegianization period (Hansen 2011: 62). One important indication of the number of people who identify as Sámi, is the electoral roll of the Sámi Parliament, which had 15.005 people registered in 2013 (Sametinget 2013). Around $90 \%$ of the Sámi-speaking population of Norway speak the dominant Northern Sámi 
language (Sametinget 2015), and a significant part of the measures taken for the protection of the Sámi language have in practice only supported Northern Sámi ${ }^{5}$ (Mæhlum 2007: 148).

Current policies dealing with the protection and promotion of minority language rights typically also include regulations of the media, in recognition of the impact of the media on the survival of threatened languages (Mac Síthigh 2015). The online visibility and accessibility of a language have been regarded as important for its vitality, although we need to be cautious in assuming that the mere presence of a minority language online will automatically guarantee revitalization (Cunliffe and Herring 2005). According to the Central Government Communication Policy (2009), government agencies in Norway must pay special attention to Sámi speakers. The Norwegian government allocates resources to support the official use of Sámi, on state websites among other things, and central Norwegian state institutions are now providing partially translated websites in Sámi. In addition to acting as agents of status planning by allocating space and visibility to Sámi in the official sphere, in the process of translation they also act as agents of corpus planning by creating their own word lists and disseminating new official terminology (interview at the Labour and Welfare Administration).

According to my informants at the Tax Administration and the Labour and Welfare Administration, the Sámi web pages can be seen as a challenge, as they are little used in reality. For example, in the case of the Labour and Welfare Administration, there were 824 unique visits to the Sámi pages in 2013, but many of them left the page almost immediately (Google Analytics statistics for 2013, received by e-mail). The 87 fact sheets translated into Sámi were practically not read at all, and only 27 of them were opened 10 times or more. Similarly, my informant at the Tax Administration pointed out that the surveys they had conducted about the specific forms and brochures online had shown that the Sámi pages are used very little. I asked my informants for their opinion about the reasons why the Sámispeaking population does not make much use of the offer to read state information and to communicate with the authorities online in Sámi. The main assumptions pointed out by them in the interviews can be summarized as follows: (1) Sámi-speakers prefer to communicate with the state in Norwegian, as it is the more dominant language; (2) Sámi-speakers are not used to referring to certain concepts in the Sámi language, or to making online searches in Sámi, at least when it comes to 'official' topics; (3) Sámi is used more in oral than written

\footnotetext{
${ }^{5}$ In most official contexts in Norway, 'Sámi' is in fact identical with Northern Sámi (Mæhlum 2007: 148). From here on, 'Sámi’ refers to Northern Sámi.
} 
communication; (4) Sámi translations are of low quality and not trusted by the Sámi speakers. In fact, several complaints regarding the quality of the Sámi translations have been received by the Labour and Welfare Administration, which may be connected to the fact that at the time of the data collection, the institution did not employ anyone to double-check the translations. The interviews further show that for the people who work with the creation and/or implementation of communication policies at the state institutions, it is first and foremost important to comply with the law regarding official use of Sámi. Their individual beliefs regarding the inevitability of Sámi speakers using the Norwegian version can result in only a bare minimum of information being translated. However, the fact that despite investments into translations, the Sámi pages and fact sheets are not well distributed or popular among the target group was mentioned as an important issue to try to improve.

The tendency reported in the interviews for Sámi speakers to use Norwegian in communication with the authorities does not come as a surprise. There are hardly any monolingual Sámi speakers in Norway, and Norwegian can be regarded as the 'exoglossic written standard' (Auer 2005) for the Sámi speakers, or the dominant language in most of the prestigious sectors of the society (Laakso et al. 2016). An important point to keep in mind is that despite the official legislation now supporting the revitalization of Sámi, language attitudes among the Sámi population still remain negatively affected by past assimilation politics (Hansen 2011). Furthermore, 'the move to the Internet involves agreeing to a written standard and a command of that written standard' (Pietikäinen and Kelly-Holmes 2011: 65). Despite the establishment of an educational system in Sámi, its first decades were characterized by a shortage of educational programs and textbooks in Sámi (Trosterud 2005). Such a situation gives good grounds to believe that many Sámi speakers lack competence in Sámi when it comes to official written communication and use the majority language instead. There is therefore a risk that official regulations will be at odds with real-life practices of the Sámi speakers.

Creating Sámi websites by Norwegian state institutions illustrates a situation of information provision in a minority language which is not necessarily motivated by a desire to provide full information which otherwise would not be understood, but rather by a necessity to comply with official regulations. Parallels can be found between the use of Sámi by Norwegian state institutions and the use of Irish by public bodies in Ireland, which also appears to have little functional importance (Walsh 2012). Ivković and Lotherington (2009) discuss two main tendencies of content presentation on state websites (these two main 
functions of the LL were initially outlined by Landry and Bourhis 1997): informational (that is more pragmatic and can be measured by its efficiency and relevance) and symbolic (that sends a socio-political message). The use of Sámi in the institutional VLL in Norway seems at the moment still to belong more to the latter. However, this might be a transitional phase, as Sámi websites (and the specific lexicon used there) are still a relatively new phenomenon. The 'Catherine Wheel' language planning model by Strubell (2001; see also Walsh and McLeod 2008) shows how institutional recognition and support can have a reflexive impact on the process of language revitalization. This model demonstrates how the supply of goods and services in a particular language can lead to an increased consumption of these goods and services in that language, which in its turn leads to a greater perception of usefulness of the language, a greater motivation to use and learn that language, more demand for goods and services in the language and back to even greater supply and consumption of goods and services in the particular language. The increased visibility of Sámi in spaces of official communication not only reflects the status of this language in Norway but could also be a significant factor in shaping the way Sámi is being perceived and used, through normalizing its use in the official space (Pietikäinen et al. 2011; Puzey 2012). However, the potential success of this model depends to a certain extent on whether the provision of translation is indeed met by a greater use of the state websites by the Sámi speakers.

4.4. English - a solution for communication with 'all the rest'?

English in Norway can be considered more a second language rather than a foreign language (Hellekjær 2007; Rindal and Piercy 2013). From the perspective of the concentric circles of English (Kachru 1985), Norway belongs to the category of 'expanding circle' countries, where English plays no historical or governmental role but is widely used as a medium of international communication. However, in Scandinavia there is far more extensive use of English than in several of the countries where it is an official second language, and English has become an integrated part of Norway's total linguistic repertoire, both at the societal and individual level (Mæhlum 2007). Domain loss for Norwegian in favor of English is reported for many sectors of the society, most notably inside higher education, research (Ljosland 2011), and the business sector (Mæhlum 2007: 166). The use of English on Norwegian state 
websites was never problematized by the interviewees who participated in this study, and was rather treated as normal and as something that goes without saying.

In the regulations stated in the Central Government Communication Policy (2009: 16) regarding other languages than Norwegian used in state communication, English is the only language explicitly named in addition to Sámi:

In order to reach the immigrant population with government information, every single agency shall consider whether it is sufficient to translate into English, or whether translations into other languages are needed as well. (Official translation)

Immigrant languages are not further discussed in any detail in this policy. This resonates with the analysis of Finnish policy documents by Nikula et al. (2012: 58) where they note the use of all-encompassing references such as 'students with immigrant backgrounds' as 'a way to downplay the linguistic heterogeneity within this group'.

As the data show, English has become a sort of default language for online state communication, 'covering' also those linguistic groups that are online but do not have sufficient Norwegian skills. Using English only can be explained not just with pragmatic or economic reasons; it must be taken into account that adding one immigrant language to a state website can raise questions about the lack of other immigrant languages. As Kelly-Holmes and Milani (2013: 13) put it, English 'is perceived as the most "neutral", "civilized", "inclusive" and "tolerant" option in a chaotic, multilingual world'. However, as pointed out by Wee (2010: 422), 'the very idea of language neutrality is deeply ideological in nature, since it is not only an attempt to treat language itself as a homogenous entity, but also the group of speakers (typically understood as the ethnic group or the nation) for whom the language represents some policy-related concern'. According to de Swaan's (2001) 'global language system' that divides languages into peripheral, central, supercentral, and hypercentral languages, English is the only hypercentral language - and this is also reflected in the position of English in cyberspace. Furthermore, English is fetishized as the language of modernity and technology. As the language of the initially monolingual cyberspace, it has 'a historical advantage in relation to the Internet and continues to dominate many online contexts' (Danet and Herring 2007: 22). A tendency for large organizations to use English in complex multilingual situations in cyberspace has been described by Kelly-Holmes (2013: 135 ) in her analysis of the management of multilingualism on the websites of global corporations, which opt for English instead of 'attempting to fulfill the impossible task of addressing everyone in their own language'. This way, instead of trying to come to terms with 
'the messy realities of an increasingly multilingual everyday social life' (Blommaert et al. 2012: 13) by addressing the different immigrant groups in their own language, Norwegian state institutions use English to cover 'international' linguistic groups.

The use of English in the institutional VLL in Norway can thus be explained by both instrumental and symbolic reasons: on the one hand, English is expected to function as a lingua franca, while on the other hand, it is perceived as a more neutral choice, since it has become detached from its origins and associations with specific cultures and geographical locations, unlike other foreign languages. Finally, it can be assumed that due to the very high English proficiency levels in Norway (Education First 2015), creating and maintaining a website in English is the easiest solution for the state institutions, as many updates and translations can be done in house, rather than having to be outsourced.

\section{Conclusions}

The diachronic analysis of state websites in Norway shows that the VLL of the country's public sector has in recent years become less and not more multilingual, despite the fact that the Web is becoming increasingly multilingual and the technology for creating multilingual content has become better. Although there has been a qualitative increase in information in several languages, we are witnessing decreasing linguistic diversity on central websites of the increasingly more diverse Norwegian nation-state. The analysis showed that the use of Nynorsk is central for state institutions, mainly because it is required by the law. There is also a growing inclusion of Sámi in the institutional VLL, which sends a sociopolitical message, but websites in Sámi are not much used by the Sámi speakers, or at least not yet.

Institutional decisions about language policy in the VLL ultimately reflect power relations in the Norwegian society. Limiting linguistic options on state websites to those languages that have an official status in Norway, and 'hypercentral' English with high prestige can have the consequence, even if an indirect one, of influencing the social architecture through shaping an understanding among Norway's population about the status and value of different languages in the society. Leaving out a language can have not only practical consequences but also symbolic implications, as a lack of visibility for that language could lead to its perceived lower status.

A central reason for the trend in the decrease of multilingualism in the institutional VLL is given as the growing digitization of public services. State websites have become the 
primary means of communication between the state and the people in Norway, and their goal is no longer to provide information about the institution but rather to function as a virtual service center. It is therefore seen as crucial by those who create them that the websites be constantly revised to provide clear and updated information. The interviews showed that the people who work with the creation and/or implementation of communication policies at Norwegian state institutions regard the maintenance of multilingual pages as a challenge. In reality, the websites of the three institutions in focus exist more or less fully only in two language versions: Bokmål and English. The translations into Nynorsk and Sámi are mainly done to comply with the official regulations, and the Sámi pages often provide only minimum information.

Immigrants thus need to know Norwegian or English in order to communicate with the authorities online, as recent changes have led to linguistic erasure (Irvine and Gal 2000) of immigrant languages from state websites (even if this simply means absence from a dropdown menu presenting various languages). The linguistic rights of immigrants are not protected by state legislation, and their languages are thus 'not included in the multilingual spectre of the state' (Blommaert et al. 2009: 205; see also Kymlicka 1995). Their removal from online communication is therefore the simplest solution when an institution has reached a 'tipping-point' in the management of an increasingly multilingual website. One could perhaps even go so far as to see Norway as the harbinger of change: once multilingualism has reached its peak, there is a chance that more and more state institutions will cut down on 'less than necessary' languages online. This way, globalization and immigration do not necessarily lead to an increased visibility of language diversity in the VLL connected to the public sector but can also put pressure towards homogenization. This hypothesis should be tested in the context of other countries, in order to find out whether the described tendency is uniquely informed by Norwegian ideology, or whether it is becoming a wider trend amongst multilingual nation-states in the cyberspace era. Finally, it should be emphasized that this article has given primary attention to the use of different languages on state websites from a top-down perspective. Further research could take into account more bottom-up views as well and investigate the perception of multilingual state websites by the population and user experiences of particular online services. 


\section{References}

Ajsic, A., \& McGroarty, M. (2015). Mapping Language Ideologies. In F.M. Hult \& D.C. Johnson (Eds.), Research Methods in Language Policy and Planning: A Practical Guide (pp. 181-192). Hoboken, NJ: John Wiley \& Sons.

Atkinson, D., \& Moriarty, M. (2012). 'There's no excuse. Speak Catalan!'- the marketing of language acquisition to mobility students. International Journal of Applied Linguistics, 22(2), 189-204.

Auer, P. (2005). Europe's sociolinguistic unity, or: A typology of European dialect/standard constellations. In N. Delbecque, J. van der Auwera, \& D. Geeraerts (Eds.), Perspectives on Variation: Sociolinguistic, Historical, Comparative (pp. 7-42). Berlin/New York, de Gruyter.

Ben-Rafael, E., Shohamy, E., Amara, M. H., \& Trumper-Hecht, N. (2006). Linguistic Landscape as Symbolic Construction of the Public Space: The Case of Israel. International Journal of Multilingualism, 3 (1), 7-30.

Blackwood, R. (2015). LL explorations and methodological challenges: Analysing France's regional languages. Linguistic Landscape: An international journal, 1(1-2), 38-53.

Blommaert, J, Kelly-Holmes, H., Lane, P., Leppänen, S., Moriarty, M., Pietikäinen, S., \& Piirainen-Marsh, A. (2009). Media, multilingualism and language policing. Language Policy, $8,203-207$.

Blommaert, J., Leppänen, S., \& Spotti, M. (2012). Endangering Multilingualism. In J. Blommaert, S. Leppänen, P. Pahta, \& T. Räisänen (Eds.), Dangerous Multilingualism. Northern Perspectives on Order, Purity and Normality (pp. 1-24). Basingstoke: Palgrave Macmillan.

Bortzmeyer, S. (2012). Multilingualism and Internet Governance. In L. Vannini \& H. Le Crosnier (Eds.), NET.LANG. Towards the Multilingual Cyberspace (pp. 372-384). Retrieved on 24 February 2016, from http://unesdoc.unesco.org/images/0021/002166/216692e.pdf

Bourdieu, P. (1991). Language and Symbolic Power. Cambridge: Harvard University Press.

Bull, T. (2004). Nynorsk som minoritetsspråk [Nynorsk as a minority language]. Språknytt, 3$4,36-39$.

Central Government Communication Policy (2009). Retrieved on 24 February 2016, from https://www.regjeringen.no/en/dokumenter/central-government-communicationpolicy/id582088/

Cunliffe, D., \& Herring, S. C. (2005). Introduction to minority languages, multimedia and the web. New Review of Hypermedia and Multimedia, 11(2), 131-137.

Danet, B., \& Herring, S. C. (Eds.). (2007). The multilingual Internet: Language, culture, and communication online. Oxford University Press. 
De Swaan, A. (2001). Words of the World: The Global Language System. Cambridge: Polity Press.

Deumert, A. (2014). Sociolinguistics and Mobile Communication. Edinburgh University Press.

Digital Agenda for Norway (2013). Retrieved on 24 February 2016, from https://www.regjeringen.no/en/dokumenter/meld.-st.-23-2012-2013/id718084/

Digitising Public Sector Services - Norwegian eGovernment Program (2012). Retrieved on 24 February 2016, from https://www.regjeringen.no/en/dokumenter/digitization-publicsector-services/id698435/

Education First (2015). EF English proficiency index. Retrieved on 24 February 2016, from http://www.ef.no/epi/

Gorter, D. (2013). Linguistic landscapes in a multilingual world. Annual Review of Applied Linguistics, 33, 190-212.

Gramstad S. (1996). Minority languages in Europe: a presentation. Det Norske Samlaget. (In Norwegian)

Grepstad, O. (2015). Language facts 2015. A story about languages in Norway and the world through 800 tables. Nynorsk kultursentrum. (In Norwegian)

Hall, S. (Ed.). (1997). Representation: Cultural representations and signifying practices (Vol. 2). Sage.

Hansen, K.L. (2011). Ethnic discrimination and bullying in relation to self-reported physical and mental health in Sami settlement areas in Norway: The SAMINOR study. A dissertation for degree of Philosophiae Doctor. University of Tromsø.

Haugen, E. (1962). Schizoglossia and the Linguistic Norm. Georgetown University Monograph Series on Language and Linguistics, 15, 63-73.

Hellekjær, G. O. (2007). The implementation of undergraduate level English medium programs in Norway: An explorative case study. In R. Wilkinson \& V. Zegers (Eds.), Researching content and language integration in higher education (pp. 68-81). Valkhof Pers.

Hine, C. (2000). Virtual Ethnography. London: Sage.

Hine, C. (2015). Ethnography for the Internet: Embedded, Embodied and Everyday. Bloomsbury Publishing.

Hiss, F. (2013). Troms $\varnothing$ as a "Sámi Town”? Language ideologies, attitudes, and debates surrounding bilingual language policies. Language Policy, 12(2), 177-196.

Indrebø Ims, I. (2007). It is us who decide the way people speak and write. A study of Norwegian newspapers' normative principles and practice regarding language. Master thesis. University of Oslo. (In Norwegian) 
Irvine, J. T. and S. Gal. 2000. Language ideology and linguistic differentiation. In Regimes of language, ed. P. Kroskrity, 35-83. Santa Fe: School of American Research Press.

Ivković, D., \& Lotherington, H. (2009). Multilingualism in cyberspace: conceptualizing the virtual linguistic landscape. International Journal of Multilingualism, 6(1), 17-36.

Kelly-Holmes, H., \& Milani, T. (2013). Thematising multilingualism in the media. Amsterdam, John Benjamins.

Kelly-Holmes, H. (2014). Linguistic fetish: The sociolinguistics of visual multilingualism. Visual Communication, 4, 135.

Kelly-Holmes, H. (2015). Analyzing Language Policies in New Media. In F.M. Hult \& D.C. Johnson (Eds.), Research Methods in Language Policy and Planning: A Practical Guide (pp. 130-139). Hoboken, NJ: John Wiley \& Sons.

Kornai, A. (2013) Digital Language Death. PLoS ONE, 8(10).

Kymlicka, W. (1995). Multicultural citizenship: A liberal theory of minority rights. Oxford: Clarendon Press.

Laakso, J., \& Sarhimaa, A. (2016). Towards Openly Multilingual Policies and Practices: Assessing Minority Language Maintenance Across Europe (Vol. 11). Multilingual Matters.

Landry, R., \& Bourhis, R. Y. (1997). Linguistic landscape and ethnolinguistic vitality an empirical study. Journal of language and social psychology, 16(1), 23-49.

Ljosland, R. (2011). English as an Academic Lingua Franca: Language policies and multilingual practices in a Norwegian university. Journal of Pragmatics, 43, 991-1004.

Mac Síthigh, D. (2015). Because the computer speaks English? Language rights and digital media. Journal of Media Law, 7(1), 65-84.

Malinowski, David (2009). 'Authorship in the Linguistic Landscape. A MultimodalPerformative View', in Elana Shohamy and Durk Gorter (eds.), Linguistic Landscape. Expanding the Scenery. Abingdon: Routledge, 107-25.

Mæhlum, B. (2007). Confrontations: When languages meet. Oslo: Novus Forlag. (In Norwegian)

Mållova (1980). Retrieved on 24 February 2016, from https://lovdata.no/dokument/NL/lov/1980-04-11-5

Nikula, T., Saarinen, T., Pöyhönen, S., \& T. Kangasvieri (2012). Linguistic diversity as a Problem and a Resource - Multilingualism in European and Finnish Policy Documents. In J. Blommaert, S. Leppänen, P. Pahta, \& T. Räisänen (Eds.), Dangerous Multilingualism. Northern Perspectives on Order, Purity and Normality. Basingstoke: Palgrave Macmillan. 
Noregs Mållag 13.01.2014. Newspapers in Nynorsk are affected to a greater extent than newspapers in Bokmål. Retrieved on 24 February 2016, from http://www.nm.no/tekst.cfm?id=3764. (In Norwegian)

Pavlenko, A. (2010). Linguistic landscape of Kyiv, Ukraine: A diachronic study. In E. Shohamy, M. Barni \& E. Ben Rafael (Eds.), Linguistic landscape in the city (pp. 133-150). Bristol, UK: Multilingual Matters.

Pietikäinen, S., \& Kelly-Holmes, H. (2011). Gifting, service, and performance: three eras in minority-language media policy and practice. International Journal of Applied Linguistics, 21(1), 51-70.

Pietikäinen, S., Lane, P., Salo, H., \& Laihiala-Kankainen, S. (2011). Frozen actions in the Arctic linguistic landscape: A nexus analysis of language processes in visual space.

International Journal of Multilingualism, 8(4), 277-298.

Puzey, G., 2012. Two-way traffic: How linguistic landscapes reflect and influence the politics of language. In D. Gorter, H.F. Marten \& L. Van Mensel (Eds.), Minority Languages in the Linguistic Landscape (pp. 127-147). Palgrave Macmillan UK.

Rindal, U., \& Piercy, C. (2013). Being 'neutral'? English pronunciation among Norwegian learners. World Englishes, 32(2), 211-229.

Røyneland, U. (2013). Norwegian language reforms in the 21st century. In Terje Lohndal (Ed.), In search of universal grammar: From old Norse to Zoque (pp. 53-76). Amsterdam: John Benjamins.

Sameloven (1987). Retrieved on 24 February 2016, from https://lovdata.no/dokument/NL/lov/1987-06-12-56 (In Norwegian)

Sametinget (2013). Electoral roll of the Sámi Parliament 2013. Retrieved on 24 February 2016, from https://www.sametinget.no/Valg-ogmanntall/Kampanjeside/Valgmanntall/Sametingets-valgmanntall-2013 (In Norwegian)

Sametinget (2015). Facts about Sámi languages. Retrieved on 24 February 2016, from https://www.sametinget.no/Spraak/Fakta-om-samiske-spraak (In Norwegian)

Shohamy, E. G. (2006). Language policy: Hidden agendas and new approaches. Psychology Press.

Statistics Norway (2016). Retrieved on 24 February 2016, from https://www.ssb.no/en

Stjernholm, K. (2015). Two Faces of Oslo: A comparative study of sense of place. In M. Laitinen \& A. Zabrodskaja (Eds.), Dimensions of Sociolinguistic Landscapes in Europe. Materials and Methodological Solutions (pp. 77-104). Peter Lang Publishing Group.

Strubell, M. (2001). Catalan a decade later. In J.A. Fishman (Ed.), Can threatened languages be saved? Reversing language shift, revisited: A $21^{\text {st }}$ centrury perspective (pp. 260-283). Clevedon UK: Multilingual Matters. 
Thorne, S. L., \& Ivković, D. (2015). Multilingual Eurovision meets plurilingual YouTube. Dialogue in Multilingual and Multimodal Communities, 27, 167.

Trosterud, T. (2005). Sámi and Kven in Norway after 1905. Språknytt, 1-2/2005. (In Norwegian)

Trosterud, T. (2008). Language Assimilation During the Modernisation Process: Experiences from Norway and North-West Russia. Acta Borealia, 25:2, 93-112.

Troyer, R. A. (2012). English in the Thai linguistic netscape. World Englishes, 31(1), 93-112.

Walsh, J. (2012). Language policy and language governance: a case-study of Irish language legislation. Language Policy, 11(4), 323-341.

Walsh, J., \& McLeod, W. (2008). An overcoat wrapped around an invisible man? Language legislation and language revitalisation in Ireland and Scotland. Language Policy, 7(1), 21-46.

Wee, L. (2010). Neutrality in language policy. Journal of Multilingual and Multicultural Development, 31:4, 421-434.

World Economic Forum (2015). The top 10 nations for bridging the digital divide. Retrieved on 24 February 2016, from http://www.weforum.org/agenda/2015/04/which-nations-are-topfor-digital/

Zabrodskaja, A. (2014). Tallinn: monolingual from above and multilingual from below. International Journal of the Sociology of Language, 2014(228), 105-130.

\section{Acknowledgements}

This work was partly supported by the Research Council of Norway through its Centres of Excellence funding scheme, Project Number 223265. I would like to thank the two anonymous reviewers for their valuable comments. I am also grateful to my $\mathrm{PhD}$ supervisors Unn Røyneland, Helen Kelly-Holmes and Aneta Pavlenko and to my colleagues at MultiLing for their feedback on an earlier draft of this article. 